\title{
Advances in the production of human monoclonal antibodies
}

This article was published in the following Dove Press journal:

Antibody Technology Journal

28 June 2011

Number of times this article has been viewed

\section{Shixia Wang}

Department of Medicine, University of Massachusetts Medical School, Worcester, MA, USA
Correspondence: Shixia Wang, Associate Professor of Medicine, Department of Medicine, University of Massachusetts Medical School, 364 Plantation Street, Worcester, MA 01605, USA

Email shixia.wang@umassmed.edu
Abstract: Since the development of hybridoma technology over three decades ago, numerous monoclonal antibodies have been produced and the use of monoclonal antibodies has become one of the major breakthroughs in medicine. Significant progress has been made on new technologies for generating human monoclonal antibodies. This review serves as an introduction to the immortalization of antigen-specific human B cell and hybridoma technologies, phage display platform, the use of transgenic mice, and the generation of monoclonal antibodies from single B cells.

Keywords: human monoclonal antibody, B cells, hybridoma, phage display, transgenic mice, immunoglobulin gene cloning

\section{Introduction}

A monoclonal antibody (MAb) is derived from a single clone of cells and recognizes a unique antigenic determinant. Since 1975, when Keller and Milstein developed hybridoma technology, technological strides towards the production of antibodies have been made. The first success in generating human mAbs (hmAbs) with predefined specificity was conducted in 1980 through the fusion of human spleen cells from patients with human myelomas. ${ }^{1}$ Since then, several major methods have been established to generate hmAbs, including 1) immortalization of antigen-specific human B cells; ${ }^{2,3}$ 2) acquisition of antigen-specific human B cells via phage display technology; 4,5 3) the production of hmAbs from transgenic mice; ${ }^{6-8}$ and 4) single human B cell cloning techniques to directly clone and express immunoglobulin (Ig) genes in vitro from antigen-specific B cells. ${ }^{9-11}$

\section{Immortalization of antigen-specific human $B$ cell and hybridoma technology}

Hybridoma technology has contributed to virtually all areas of biology and medicine and has been greatly refined since its introduction in 1975. In the early days, approaches to produce hmAb included (1) the hybridoma technique, based on the fusion of antibody-producing human B lymphocytes with either mouse or human myeloma or lymphoblastoid cells, ${ }^{12,13}$ or (2) the EBV immortalization technique, based on the use of Epstein-Barr virus (EBV) to 'immortalize' antigen-specific human B lymphocytes. ${ }^{14-16}$ Each method has its advantages and drawbacks. ${ }^{17}$ Antibodysecreting hybridomas are derived from a fusion of myeloma cells that can grow indefinitely and an immune B lymphoblast that expresses a specific antibody gene. Attempts to use the hybridoma technology for generating hmAbs have been hampered by the lack of a suitable human myeloma cell line. The best results were obtained using heteromyelomas (mouse $\times$ human hybrid myelomas) as fusion partners. Alternatively, human antibody-secreting cells can be immortalized by infection with the EBV. 
However, EBV-transformed cells cannot grow indefinitely because they are not malignant cells, are very difficult to clone, and usually produce only low yields of immunoglobulin. The EBV-hybridoma technique was established based on a combination of the two methods. ${ }^{3,18}$ The EBV-hybridoma system retains the advantageous features of the other two systems while overcoming their pitfalls for producing hmAb with a defined specificity. ${ }^{19,20}$ Rapid advances in development of methods to improve the B cell immortalization and cell fusion, such as electroporation for fusion, may well lead EBV-hybridoma technology into a new era. ${ }^{21}$

\section{Phage display}

Phage display technology, as one type of display platform, was first developed in 1985 and has been used to produce large numbers of peptides and proteins on the bacteriophage. It is the next method being successfully used to select antigen-specific variable region genes and to express functional antibody fragments with unique specificity. ${ }^{22-27}$ To isolate human antibodies, the library of diverse human immunoglobulin-heavy chain variable $(\mathrm{VH})$ gene and lightchain variable (VL) gene segments are prepared by reversetranscription of mRNA from B cells and PCR amplification. The gene encoding single chain variable fragment ( $\mathrm{scFv}$ ) can be created by randomly combining VH and VL gene segments using PCR. The large antibody repertoires can be generated using the process of combinatorial infection and in vivo recombination, to display $\mathrm{scFv}$ on the surface of the phage. ${ }^{27-29}$ After bio-panning the phages bound to a range of antigens or haptens, antigen-specific antibody fragments with good affinities can be identified. ${ }^{27,29-31}$ To date, several improvements have been made in phage display technology to increase the efficiency of the acquisition of antigenspecific scFv, to augment the affinity of scFv for antigens, and to increase the specificity of $\mathrm{scFv}^{27,29,32,33}$ One phage display-derived $\mathrm{mAb}$ has been approved by the FDA and at least 35 human mAbs generated by phage display technology have entered into clinical development. ${ }^{34}$

\section{Transgenic mice}

The transgenic mouse platform is another technology available to generate hmAbs. Genetically engineered mice expressing human antibody repertoires were first reported for generating hmAbs using the hybridoma technology in 1994. The engineered transchromosomal mice comprised of disruption of endogenous mouse Ig-heavy chain and Igא-light chain loci together with the introduction of transgenes encoding human Ig-heavy chain and Igא-light chain genes. ${ }^{6-8,35,36-38}$ Over the past few decades, progress has been made to express additional $\mathrm{V}$ gene segments by transgenic mice and to expand the potential repertoire of the recovered antibodies. ${ }^{36-38}$ Transgenic mice producing hmAbs with various heavy-chain isotypes have also been generated to tailor effector functions. At present, more than $50 \mathrm{hmAb}$ produced in transgenic mice are in clinical trials and six have been approved for marketing. ${ }^{34}$ Although immune responses in transgenic mice are sometimes less robust than those observed in wild type mouse strains that are used to generate mouse mAbs, the expression of human Ig in transgenic mice prevents human anti-mouse antibody responses and maintains the advantages of mouse hybridoma technology for the production of antibodies for potential clinical uses.

\section{Generation of mAbs from single human B cells by Ig gene cloning and expression in vitro}

A new platform to generate mAbs from single human B cells by single cell RT-PCR and expression vector cloning has been developed. ${ }^{10,11,39-41}$ This strategy is based on the combination of immunoglobulin (Ig) gene repertoire analysis and Ig reactivity profiling at the the single cell level. This approach requires the isolation of individual B cells from mouse spleen or human PBMCs using magnetic microbeads conjugated with B-cell-selective markers ${ }^{41}$ or fluorescence-activated cell sorting ${ }^{11}$ based on the cell surface marker on individual B cells. The light-chain and heavy-chain genes coding for variable fragments of antibody in each cell are separately amplified by RT-PCR and then combined with the sequences by an overlapping PCR technique. For each cell, Ig heavy- and corresponding Ig light-chain gene transcripts are amplified by nested RT-PCR and cloned into mammalian expression vectors to produce hmAb with defined specificity in vitro. Using this approach to clone and express hmAb is unbiased, highly efficient, and requires only small cell numbers. Furthermore, the recombinant antibodies allow for direct conclusions on the frequency of specific human B cells in a diverse repertoire and may be able to rapidly generate numerous antigen-specific hmAbs in a short time.

Recently, novel linear Ig heavy- and light-chain gene expression cassettes to express $\operatorname{Ig} \mathrm{V}(\mathrm{H})$ and $\mathrm{V}(\mathrm{L})$ genes isolated from single B cells as IgG1 antibody without a cloning step have been developed. ${ }^{42}$ The cassettes contain all essential elements for transcriptional and translational regulation, including CMV promoter, Ig leader sequences, constant region of IgG1 heavy- or Ig light-chain, poly(A) tail, and substitutable $\mathrm{V}(\mathrm{H})$ or $\mathrm{V}(\mathrm{L})$ genes. These Ig gene 
expression cassettes constitute a highly efficient strategy for rapid expression of Ig genes for high-throughput screening and analysis without cloning. ${ }^{42}$

With the advent of MAb technologies, human monoclonal antibodies have been widely used for development of therapeutics and diagnostics and have been used in research to dissect various humoral immune responses in humans. As a result of their natural roles and no inherent toxicity in vivo, human monoclonal antibodies have been considered as natural drugs and more than 20 therapeutic monoclonal antibodies, including humanized mouse $\mathrm{mAb}$ with human complementarity-determining regions, have been approved for clinical use in the past few decades. There are many other monoclonal antibodies at different stages of preclinical and clinical development/pipelines of pharmaceutical companies and development programs. Therefore, human $\mathrm{MAb}$ technologies are not only extremely useful strategic research tools but are also of enormous values for health economics.

\section{Disclosure}

The author discloses no conflicts of interest.

\section{References}

1. Olsson L, Kaplan HS. Human-human hybridomas producing monoclonal antibodies of predefined antigenic specificity. Proc Natl Acad Sci U S A. 1980;77(9):5429-5431.

2. MacDonald G, Primrose S, Biggins K, et al. Production and characterization of human-human and human-mouse hybridomas secreting Rh(D)-specific monoclonal antibodies. Scand J Immunol. 1987;25(5): 477-483.

3. Ainai A, Kawase T, Ida A, et al. Renewal of EBV-hybridoma method: efficient generation of recombinant fully human neutralizing IgG antibodies specific for tetanus toxin by use of tetroma cells. Hum Antibodies. 2006;15(4):139-154.

4. Gram H, Strittmatter U, Lorenz M, Gluck D, Zenke G. Phage display as a rapid gene expression system: production of bioactive cytokinephage and generation of neutralizing monoclonal antibodies. J Immunol Methods. 1993;161(2):169-176.

5. Zhao XL, Yin J, Chen WQ, Jiang M, Yang G, Yang ZH. Generation and characterization of human monoclonal antibodies to G5, a linear neutralization epitope on glycoprotein of rabies virus, by phage display technology. Microbiol Immunol. 2008;52(2):89-93.

6. Jakobovits A. Production of fully human antibodies by transgenic mice. Curr Opin Biotechnol. 1995;6(5):561-566.

7. Jakobovits A, Green LL, Hardy MC, et al. Production of antigen-specific human antibodies from mice engineered with human heavy and light chain YACs. Ann N Y Acad Sci. 1995;764:525-535.

8. Osbourn J, Jermutus L, Duncan A. Current methods for the generation of human antibodies for the treatment of autoimmune diseases. Drug Discov Today. 2003;8(18):845-851.

9. Babcook JS, Leslie KB, Olsen OA, Salmon RA, Schrader JW. A novel strategy for generating monoclonal antibodies from single, isolated lymphocytes producing antibodies of defined specificities. Proc Natl Acad Sci U S A. 1996;93(15):7843-7848.

10. Ali M, Hitomi K, Nakano H. Generation of monoclonal antibodies using simplified single-cell reverse transcription-polymerase chain reaction and cell-free protein synthesis. J Biosci Bioeng. 2006;101(3):284-286.
11. Smith K, Garman L, Wrammert J, et al. Rapid generation of fully human monoclonal antibodies specific to a vaccinating antigen. Nat Protoc. 2009;4(3):372-384.

12. De StGroth SF, Scheidegger D. Production of monoclonal antibodies: strategy and tactics. J Immunol Methods. 1980;35(1-2):1-21.

13. Kennett RH. Hybridomas: a new dimension in biological analyses. In Vitro. 1981;17(12):1036-1050.

14. Steinitz M, Klein G. EBV-transformation of surface IgA-positive human lymphocytes. J Immunol. 1980;125(1):194-196.

15. Roome AJ, Reading CL. The use of Epstein-Barr virus transformation for the production of human monoclonal antibodies. Exp Biol. 1984; 43(1):35-55.

16. Robinson JE, Holton D, Pacheco-Morell S, Liu J, McMurdo H. Identification of conserved and variant epitopes of human immunodeficiency virus type 1 (HIV-1) gp120 by human monoclonal antibodies produced by EBVtransformed cell lines. AIDS Res Hum Retroviruses. 1990;6(5):567-579.

17. Olsson L. Human monoclonal antibodies: methods of production and some aspects of their application in oncology. Med Oncol Tumor Pharmacother. 1984;1(4):235-246.

18. Yamaura N, Makino M, Walsh LJ, Bruce AW, Choe BK. Production of monoclonal antibodies against prostatic acid phosphatase by in vitro immunization of human spleen cells. J Immunol Methods. 1985; 84(1-2):105-116.

19. Cole SP, Campling BG, Atlaw T, Kozbor D, Roder JC. Human monoclonal antibodies. Mol Cell Biochem. 1984;62(2):109-120.

20. Nissim A, Chernajovsky Y. Historical development of monoclonal antibody therapeutics. Handb Exp Pharmacol. 2008;(181):3-18.

21. Yu X, McGraw PA, House FS, Crowe JE Jr. An optimized electrofusionbased protocol for generating virus-specific human monoclonal antibodies. J Immunol Methods. 2008;336(2):142-151.

22. Hoogenboom HR. Designing and optimizing library selection strategies for generating high-affinity antibodies. Trends Biotechnol. 1997;15(2): $62-70$.

23. Hoogenboom HR, Chames P. Natural and designer binding sites made by phage display technology. Immunol Today. 2000;21(8):371-378.

24. Hoogenboom HR, Henderikx P, de Haard H. Creating and engineering human antibodies for immunotherapy. Adv Drug Deliv Rev. 1998; 31(1-2):5-31.

25. Hoogenboom HR. Overview of antibody phage-display technology and its applications. Methods Mol Biol. 2002;178:1-37.

26. McCafferty J, Fitzgerald KJ, Earnshaw J, et al. Selection and rapid purification of murine antibody fragments that bind a transitionstate analog by phage display. Appl Biochem Biotechnol. 1994;47 (2-3):157-171; discussion 171-173.

27. Schofield DJ, Pope AR, Clementel V, et al. Application of phage display to high throughput antibody generation and characterization. Genome Biol. 2007;8(11):R254.

28. Williamson RA, Persson MA, Burton DR. Expression of a human monoclonal anti-(rhesus D) Fab fragment in Escherichia coli with the use of bacteriophage lambda vectors. Biochem J. 1991;277(Pt 2): 561-563.

29. Marks JD, Bradbury A. Selection of human antibodies from phage display libraries. Methods Mol Biol. 2004;248:161-176.

30. Marks JD, Hoogenboom HR, Bonnert TP, McCafferty J, Griffiths AD, Winter G. By-passing immunization. Human antibodies from V-gene libraries displayed on phage. J Mol Biol. 1991;222(3):581-597.

31. Marks JD, Ouwehand WH, Bye JM, et al. Human antibody fragments specific for human blood group antigens from a phage display library. Biotechnology (NY). 1993;11(10):1145-1149.

32. O'Connell D, Becerril B, Roy-Burman A, Daws M, Marks JD. Phage versus phagemid libraries for generation of human monoclonal antibodies. J Mol Biol. 2002;321(1):49-56.

33. Bradbury AR, Marks JD. Antibodies from phage antibody libraries. J Immunol Methods. 2004;290(1-2):29-49.

34. Nelson AL, Dhimolea E, Reichert JM. Development trends for human monoclonal antibody therapeutics. Nat Rev Drug Discov. 2010; 9:767-74. 
35. Yamashita M, Katakura Y, Shirahata S. Recent advances in the generation of human monoclonal antibody. Cytotechnology. 2007; 55(2-3):55-60.

36. Lonberg N. Human antibodies from transgenic animals. Nat Biotechnol. 2005;23(9):1117-1125.

37. Lonberg N. Fully human antibodies from transgenic mouse and phage display platforms. Curr Opin Immunol. 2008;20(4):450-459.

38. Lonberg N. Human monoclonal antibodies from transgenic mice. Handb Exp Pharmacol. 2008;(181):69-97.

39. Tiller T, Meffre E, Yurasov S, Tsuiji M, Nussenzweig MC, Wardemann H. Efficient generation of monoclonal antibodies from single human B cells by single cell RT-PCR and expression vector cloning. J Immunol Methods. 2008;329(1-2):112-124.
40. Masri SA, Rast $\mathrm{H}, \mathrm{Hu} \mathrm{WG}$, et al. Cloning and expression in E. coli of a functional Fab fragment obtained from single human lymphocyte against anthrax toxin. Mol Immunol. 2007;44(8):2101-2106.

41. Jiang X, Suzuki H, Hanai Y, et al. A novel strategy for generation of monoclonal antibodies from single B cells using rt-PCR technique and in vitro expression. Biotechnol Prog. 2006;22(4):979-988.

42. Liao HX, Levesque MC, Nagel A, et al. High-throughput isolation of immunoglobulin genes from single human B cells and expression as monoclonal antibodies. J Virol Methods. 2009;158(1-2):171-179.

\section{Publish your work in this journal}

Antibody Technology Journal is international, peer-reviewed, open access journal publishing original research, reports, reviews and commentaries on all areas of antibody technology. The manuscript management system is completely online and includes a very quick and fair

\section{Dovepress}

peer-review system. Visit http://www.dovepress.com/testimonials.php to read real quotes from published authors. 